\title{
Impact of herbs on immunomodulation in diabetes mellitus
}

\begin{abstract}
Diabetes mellitus is one of the metabolic disorder, mainly impairs the immune system of the body, as it is an autoimmune disease also. It destroys the pancreatic Langerhans $\beta$ cells of Islet of Langerhans of pancreatic by antigen-antibody reaction of $\mathrm{CD} 4+$, $\mathrm{CD} 8+, \mathrm{T}$ cells, and autoantibodies. The prevalence of diabetes and its complications are alarmingly raising worldwide. One of the major problem in case of Diabetes is decrease in cell immunity which results into various complications, Immuno modulators are group of medicines or diet supplements which increase the immunity by increasing the production of various immune stimulating agents like interferons. etc. There are many plants having a role in diabetes management. Experimental and clinical trials have shown the efficacy of plant and its constituents play an important role in the management of impaired immunity in diabetes.
\end{abstract}

Volume 5 Issue 2 - 2018

Malagi KJ, Kamath $M$

Division of Ayurveda KMC, Manipal University, India

Correspondence: KJ Malagi, Department of Ayurveda, Kasturba Medical College, Manipal University, Manipal-576I04, India,Tel 91-820-2922064/094482I568I, Email kjmalagi@gmail.com

Received: April 23, 2017 | Published: April 17, 2018

Keywords: immunomodulators, diabetes

\section{Background}

Diabetes mellitus, is one of the metabolic disorders mainly impairs the immune system of the body. DM is mainly as an autoimmune disease, $\&$ affects the immune system of the diseased by this disease. This is the main hindrance, which leads to various infectious diseases. It destroys the pancreatic Langerhans $\beta$ cells of Islet of Langerhans of pancreatic by antigen-antibody reaction of $\mathrm{CD} 4+, \mathrm{CD} 8+, \mathrm{T}$ cells and auto antibodies. The prevalence of diabetes and its complications are rising worldwide alarmingly. Now around 143 million of the world population is affected from diabetes. ${ }^{1}$ This will be doubled in $2030 .{ }^{2}$ One of the major concern in case of Diabetes is decrease in cell immunity which results into various complication's. Immuno modulators are group of medicines or diet supplements which increase the immunity by increasing the production of various immune stimulating agents like interferons.etc. There are many plants having a role in diabetes management. Experimental and clinical trials have shown the efficacy of plant and its constituents play an important role in the management of impaired immunity in diabetes. Interestingly, the results of experimental studies on diabetic physiological molecular pathways. ${ }^{3}$ Immunomodulation helps impaired immune system response in case of immunosuppression like Diabetes, Rheumatoid arthritis, HIV etc. We have highlighted in this study the efficacious plants with their bioactive molecules are responsible for immunomodulatory action in diabetes. Indian flora consists about 45,000 plant species, ${ }^{4}$ in which three thousand plants used in the various traditional system of medicines and folk lore medicine of India.

\section{Amla (BN.Emblica Officinalis) (Family: Euphorbiaceae)}

It is also known as Indian gooseberry, the small to medium size tree, a most popular plant in Indian system of medicine Ayurveda, which exhibits therapeutic properties like possessing antioxidant, adaptogenic, hepato-protective, Hypolipidemic, Cytoprotective, and immunomodulator in nature. ${ }^{5} \mathrm{~A}$ number of dosage modalities are explained in all most all Ayurvedic treaties. It is one among the world famous drug combination Triphala (A poly herbal drug combination). It has been used for the purposes of promoting longevity, anti-inflammatory and active against HIV. It also maintains the lymphocyte proliferation, interleukin production. Its antioxidant property is mainly because of the presence of rich Vitamin $\mathrm{C}$ along with tannins like camellia Sinensis. It also contains pectin reduces serum cholesterol levels, ${ }^{6}$ while it also favors in maintaining the blood pressures. ${ }^{7.8}$ It exhibits immunomodulatory effect by inhibiting the production of ConA-induced IL-2 and g-IFN.

\section{Bitter melon or bitter gourd (BN. Momordica character) (Family: Cucurbitaceae)}

A plant climber plant, M.charantia is used as a food and as well as medicine. It is also used as an antimicrobial, anti-inflammatory, and antihelminthic agent. It contains active principles like steroidal saponin polypoid $-\mathrm{p}$ and alkaloid momo ricin. Presently more than 0 ne fifty various studies of different dosage modalities of $M$. character to evaluate its anti-hyperglycemic and hypoglycemic effects the polypeptide-p useful in the management of DM. In vivo studies reveals that its chemical constituents exhibits immunostimulatory effect ${ }^{9}$ and its immune stimulatory action is mainly due to the increase in interferon and cell-mediated immunity. ${ }^{10}$

\section{Krishna jiraka (BN. Nigella sativa) (Family: Ranunculaceae)}

N.sativa popularly known as Black seeds, a dicotyledon fruit exhibits various medicinal properties like anti-diabetic, antiinflammatory and anti-histaminic properties. ${ }^{11}$ It is used as both spices in the kitchen and as a medicine. It exhibits both antihypertensive and anti diabetic properties. It escalates the anti-oxidant mechanism and thus prevents the lipid-peroxidation in diabetes. ${ }^{12}$ Oral administration of ethanol extract of N. sativa seeds reduces blood glucose levels, as well as lipids in experimental animals. ${ }^{13}$ It mainly control the hepatic gluconeogenesis $^{14,15}$ and no adverse events like renal and hepatic toxicity were reported. ${ }^{16}$

\section{Kumari (BN. Aloe vera) (Family:Asphodelaceae)}

Aloe vera is a cactus-like plant.It mainly contains chemical constituents like anthraquinones, phenolic compounds, which exhibit antibacterial property against Gram-positive bacteria's. ${ }^{17}$ While it also 
contains polysaccharides and contains vitamins, enzymes ${ }^{18}$ it also possess antidiabetic property and increases immunity, and enhances the immune stimulation action ${ }^{19}$ as it contains polysaccharides. ${ }^{20,21}$

\section{Raja Bala (BN. Sida cordiflia) (Family: Malvaceae)}

Its possess aphrodisiac, anti-diabetes properties, and it is useful in treating the neurological disease conditions like hemiplegia, Bell's palsy etc. ${ }^{22}$ It posses hypoglycemic effect by stimulating beta cell ${ }^{23,24}$ it also arrest the oxidative stress and free radical formation and useful in diabetes.

\section{Guava (BN. Psidium guajava) (Family: Myrtaceae)}

It is an evergreen shrub or small tree, cultivated in tropical and subtropical regions. The important phytoconstituents of guava are vitamin C, tannins, flavonoids, Leaves contain tannins, isoflavonoids, kaempferol and posses antioxidant, anti-hyperglycemic, analgesic actions. ${ }^{25}$ Guava has been used for centuries in the Indian traditional system of medicine and folklore medicine Leaves contains number of flavonoids, one among them is quercetin which are the plasma glouse levels in experimental animal models. ${ }^{26,27}$

\section{Gymnema (BN. Gymnema sylvestre) (Family: Asclepiadaceae)}

It plays the main role in the management of noncommunicable diseases like obesity, diabetes, cancer, hepatotoxicity, hyperlipidemia etc. In Ayurveda, it is used for manifestations like diabetes, snake bite, etc. ${ }^{28}$ It contains active principles gymnemic acids, gymnemasaponins, helps to control fasting sugar. ${ }^{29}$ It possess immunostimulatory action ${ }^{30}$ so it is useful in conditions like immunomodulation. It plays a major role in radiation-induced hepatic injury. ${ }^{31}$

\section{Neem (BN. Azadirachta indica) (Family: Meliaceae)}

Neem is extensively used in the various traditional system of medicine. Each part of neem is having its own therapeutic properties. It contains chemical constituents like Nimbin, nimbinin, nimbidinin etc. Neem possess various biological and medicinal properties like anti-bacterial,anti-fungal, antiviral ant diabetic one, its seeds oil acts a s spermicidal so it is used as a contraceptive.$^{32}$ Experimental studies reveals that Neem oil treatment significantly produces of gamma interferon as well as lymphocyte proliferative. ${ }^{33}$ Neem extracts are helpful in combating the HIV. ${ }^{34}$ Its aqueous extract stimulates cellmediated Immunostimulant activity

\section{Garlic (BN. Allium sativum) (Family:Amaryllidaceae)}

In Ayurveda, it is used as a digestant, carminative one. External application of a paste of garlic is beneficial in arthritis pain, headache etc. ${ }^{35}$ Advance in research shows that it is useful in atherosclerosis. It also acts as an antimicrobial, antifungal, anti helmentic, anti lipidemic and antithrombotic one. Other properties are antidiabetic as well as antioxidation so it prevets the peroxidase formation. It is rich in organo sulphur compounds. Garlic is a familiar spice which acts as antioxidant hypocholesterolemic, anti-inflammatory agent, hypolipidemic agent, and antidiabetic one. It may produce bleeding when used along with analgesics and anticoagulants like paracetamol, aspirin, and warfarin. ${ }^{36}$ It promotes interleukin-2, gamma interferon and acts as an immunostimulator. ${ }^{37}$ It also useful in some kind of tumors. ${ }^{38}$

\section{Guduchi (BN. Tinosopra cordifolia) (Family: Menispermaceae)}

This plant can be used in various dosage modalities in Ayurveda. In Ayurveda, it has been used in various disease conditions like fever, jaundice, and in different types of skin diseases. It exhibits various medicinal properties like anti-oxidant, immunomodulatory, ${ }^{39}$ anti-diabetic, anti-inflammatory, anti-arthritic etc. The plant posses $p$ immunomodulatory effect, by enhancing the phagocytic activity and production of macrophages, and reactive oxygen species. ${ }^{40}$ It also useful in diabetes by arresting oxidative stress. ${ }^{41}$

\section{Discussion}

$80-85 \%$ of the population of the world population still depends upon herbal medicines in the treatment of Diabetes. These traditional plant origin medicines can be used as vegetables and also in the form of various dosage modalities. Traditional medicines can be used as in form of herbal, folklore, and as a phytomedicine. In general, people use these medicines as a dietary supplements, nutraceuticals as well as medicine with the preoccupied thought that these are safe. Public use these medicines due to an extensive history of use. The main issues related to the herbal medicines are improper functioning of the governing body it's because Lack of awareness in people. No good manufacturing practices (GMP), Good clinical practices (GCP) etc. The other issues are related to herbal medicines is herb-drug interaction, food-drug interaction. ${ }^{42} \mathrm{~A}$ remarkable effort is required to evaluate active principles this anti-hypoglycemic of Indian medicinal plants under the limelight of pharmacology. ${ }^{43,44}$

\section{Conclusion}

Diabetes is a metabolic disorder, which engulfs large population of the world associated with decreased insulin production \& immunosuppression or lack of resistance to infection. Plants origin medicines have been used to boost immunity in diabetes patients. Several types of research have proved the role of plant origin medicines in the management of diabetes with a ray of hope. We recommend extensive research to assess these plant based products with various parameters like dosage fixation, toxicological studies, reporting and analyzing herb-drug interaction etc.

\section{Acknowledgement}

None.

\section{Source of support}

Nil.

\section{Conflict of interest}

None declared.

\section{References}

1. Kingh H, Aubert RE, Herman WH. Global burden of diabetes, 19952025: prevalence, numerical estimates, and projections. Diabetes Care. 1998;21(9):1414-1431.

2. Harris MI, Flegal KM, Cowie CC, et al. Prevalence of diabetes, impaired fasting glucose, and impaired glucose tolerance in U.S. adults. The Third National Health and Nutrition Examination Survey, 1988-1994. Diabetes Care. 1998;21(4):518-524. 
3. Mentreddy SR. Medicinal plant species with potential anti diabetic properties. J Sci Food Agric. 2007;87:743-750.

4. Grover JK, Yadav S, Vats V. Medicinal plants of India with anti-diabetic potential. J Ethnopharmacol. 2002;81(1):81-100.

5. M Sai Ram M, Neetu D, Yogesh B, et al. Cyto-protective and immunomodulating properties of Amla (Emblica officinalis) on lymphocytes: an in-vitro study. J Ethnopharmacol. 2002;81(1):5-10.

6. Bhattacharya A, Chatterjee A, Ghoshal S, et al. Antioxidant activity of active tannoid principle of Emblica offinalis (Amla). Indian $J$ Exp Biol. 1999;37(7):676-680.

7. Gopa B, Bhatt J, Hemavathi KG. A comparative clinical study of hypolipidemic efficacy of Amla (Emblica officinalis) with 3-hydroxy3-methylglutaryl-coenzyme-A reductase inhibitor simvastatin. Indian $J$ Pharmacol. 2012;44(2):238-242.

8. Grover HS, Deswal H, Singh Y, et al. Therapeutic effects of amla in medicine and dentistry: A review. J Oral Res Rev. 2015;7(2):65-68.

9. Leung SO, Yeung HW, Leung KN. The immunosuppressive activities of two abortifacient proteins isolated from the seeds of bitter melon (Momordica charantia). Immunopharmacology. 1987;13(3):159-171.

10. Cunnick JE, Sakamoto K, Chapes SK, et al. Induction of tumor cytotoxic immune cells using a protein from the bitter melon (Momordica charantia). Cell Immunology. 1990;126(2):278-289.

11. Ali BH, Blunden G. Pharmacological and toxicological properties of Nigella sativa. Phytother Res. 2003;17(4):299-305.

12. Meral I, Yener Z, Kahraman T, Mert N, et al. Effect of Nigella sativa on glucose concentration, lipid peroxidation, anti-oxidant defence system and liver damage in experimentally-induced diabetic rabbits. $J$ Vet Med A Physiol Pathol Clin Med. 2001;48(10):593-599.

13. Kaleem M, Kirmani D, Asif M, et al. Biochemical effects of Nigella sativa L seeds in diabetic rats. Indian J Exp Biol. 2006;44(9):745-748.

14. El Dakhakhny M, Mady N, Lembert N, et al. The hypoglycemic effect of Nigella sativa oil is mediated by extrapancreatic actions. Planta Med. 2002;68(5):465-466.

15. Fararh KM, Atoji Y, Shimizu Y, et al. Mechanisms of the hypoglycaemic and immunopotentiating effects of Nigella sativa L. oil in streptozotocininduced diabetic hamsters. Res Vet Sci. 2004;77(2):123-129.

16. Salem ML. Immunomodulatory and therapeutic properties of the Nigella sativa L. seed. Int Immunopharmacol. 2005;5(13-14):1749-1770.

17. Surjushe A, Vasani R, Saple DG. Aloe vera: A short review. Indian J Dermatol. 2008;53(4):163-166.

18. Choi S, Chung MH. A review of the relationship between Aloe vera components and their biological effects. Semin. in Integrative Medicine. 2003;1(1):53-62.

19. Djeraba A, Quere P. In vivo macrophage activation in chickens with Acemannan, a complex carbohydrate extracted from Aloe vera L. Int $J$ Immunopharmacol. 2000;22(5):365-372

20. Reynolds T, Dweck AC. Aloe vera leaf gel: A review update. $J$ Ethnopharmacol. 1999;68(1-3):3-37.

21. ZhanHai Yu, Che Jin, Ma Xin, et al. Effect of Aloe vera polysaccharides on immunity and antioxidant activities in oral ulcer animal models. Carbohydrate Polymers. 2009;75:307-311

22. V Sivarajan, I Balachandran. Ayurvedic Drugs and Their Plant Sources Oxford and IBH Publishing; 1994.

23. Collier E, Watkinson A, Cleland C, et al. Partial purification and characterization of an insulin-like material form spinach and Lemna gibba G3. J Biol Chem. 1987;262(13):6238-6247.

24. Chang MLW, Johnson MA. Effect of garlic on carbohydrate metabolism and lipid synthesis in rats. Journal of Nutrition. 1980;110(5):931-936.

25. Barbalho SM, Farinazzi-Machado FM, de Alvares Goulart R, et al. Psidium guajava (Guava): A plant of multipurpose medicinal plants. Med Aromat Plants. 2012;1(4):104

26. Morales MA, Tortoriello J, Meckes M, et al. Calcium-antagonist effect of quercetin and its relation with spasmolytic properties of Psidium guajava L. Arch Med Res. 1994;25(1):17-21.

27. Ravi K, Divyashree P. Psidium guajava: A review on its potential as an adjunct in treating periodontal disease. Pharmacogn Rev. 2014;8(16):96100

28. VK Singh, S Umar, SA Ansari, et al. Gymnema sylvestre for diabetics. Journal of Herbs, Spices and Medicinal Plants. 2008: 14(1-2):88-106.

29. Galletto R, Siqueira VLD, Ferreira EB, et al. Absence of antidiabetic and hypolipidemic effect of Gymnema sylvestre in non-diabetic and alloxan-diabetic rats. Brazilian Archives of Biology and Technology. 2004;47(4):545-551.

30. Malik, JK Manvi FV, Nanjware BR, et al. Wound healing properties of alcoholic extract of Gymnema sylvestre R.Br. leaves in rats. Journal of Pharmacy Research, 2009;2:1029-1030.

31. Bhatia AL, Kamal R, Verma G, et al. Radioprotective role of gymnemic acid on mice: study on hepatic biochemical alterations. Asian J Exp Sci. 2008;22(3):427-432.

32. Chattopadhyay RR, Chattopadhyay RN, Nandy AK, et al. The effect of fresh leaves of Azadirachta indica on glucose uptake and glycogen content in the isolated rat hemi diaphragm. Bulletin of the Calcutta School of Tropical Medicine; 1987. P. 8-12.

33. Upadhyay SN, Dhawan S, Garg S, et al. Immunomodulatory effects of neem (Azadirachta indica) oil. Int J Immunopharmacol. 1992;14(7):11871193.

34. Mbah AU, Udeinya IJ, Shu EN, et al. Fractionated neem leaf extract is safe and increases CD4+ cell levels in HIV/AIDS patients. Am. J. Ther. 2007;14(4):369-374.

35. Sen P, Medinata PK, Ray A. Applicability, Feasibility and Efficacy of Phytotherapy in Aquatic Animal Health Management. Indian J Exp Biol. 1992;12:1170-1175.

36. Burnham BE. Garlic as a possible risk for postoperative bleeding. Plast Reconstr Surg. 1995;95(1):213.

37. Butt MS, Sultan MT, Butt MS, et al. Garlic: nature's protection agains physiological threats. Crit Rev Food Sci Nutr. 2009;49(6):538-551.

38. Londhe VP. Role of garlic (allium sativum) in various diseases-an overview. Journal of pharmaceutical research \& opinion. 2011;1(4):129 134.

39. Kapil A, S Sharma. Immunopotentiating compounds from Tinospora cordifolia. J Ethnopharmacol.1997;58(2):89-95.

40. Upadhyaya R, Pandey RP, Sharma V, et al. Assessment of the multifaceted immunomodulatory potential of the aqueous extract of Tinospora cordifolia. Res J Chem Sci 2011;1(6):71-79.

41. Sangeetha MK, Balaji Raghavendran HR, Gayathri V, et al. Tinospora cordifolia attenuates oxidative stress and distorted carbohydrate metabolism in experimentally induced type 2 diabetes in rats. J Nat Med. 2011;65(3-4):544-550.

42. Malagi KJ, Kamath M, Adiga SH. Herb-Drug Interaction in Diabetes: a Bane or a Boon. J Diabetes Metab Disord Control. 2014;1(3):00013.

43. Li WL, Zheng HC, Bukuru J, Kimpe ND. Natural medicines used in the traditional Chinese medical system for therapy of diabetes mellitus. J Ethnopharmacol. 2004;92(1):1-21.

44. Kokate CK, Purohit JP, Gokhale SB. Pharmacognosy. 31st edn. Nirali Prakashan: Pune; 2005. P. 133-599. 